\title{
Law Enforcement of Money Laundering: Case Studies on Fighting Narcotic Crime
}

\author{
Sri Heny Alamsari* Irwansyah, Muhadar Wiwie Heryani \\ Faculty of Law, Hasanuddin University, South Sulawesi, Indonesia
}

\begin{abstract}
The research was based on the fact of increasing narcotics crime, both quantitatively and qualitatively as well as it has begun become a transnational organized-crime. It is an empirical-legal research. The site of research was the National Narcotics Agency. It was designed to look at the relationship between the three independent variables (investigation, arrest, and investigation of drug leader assets) on the effectiveness of law enforcement on the drug leader case as dependent variable. The hypothesis of research indicates that the more intense of investigation, arrest and investigation of narcotics asset, the higher of effectiveness of law enforcement in narcotics leader case.
\end{abstract}

Keywords: Narcotics, Money Laundering, Transnational Crime

DOI: $10.7176 / \mathrm{JLPG} / 88-22$

Publication date: August $31^{\text {st }} 2019$

\section{Introduction}

Globalization era was designed to bring benefits to the advancement of humanity, but also it creates various forms of international scale-organized crime. Transnational crime is growing more rapidly without bound by regional boundaries or commonly known as transnational organized crime. The term transnational crime is an identification of new characteristics of contemporary forms of organized crime that have emerged and widely discussed by a number of international organizations. ${ }^{1}$

As a worldwide crime, the activities of transnational crime organizations include the drug trafficking industry, smuggling of illegal migrants, arms trafficking, trafficking in nuclear material, transnational criminal organizations and terrorism, trafficking in women and children, trafficking in body parts, theft and smuggling of vehicles, money laundering, and other types of activities are very concerned about the international community. ${ }^{2}$ community. $^{2}$

A change in perspective on crime has resulted in new developments in criminological studies, namely the identification of crimes that are able to manipulate or change the proceeds of crime from illegal to legal. The object of the activities is money or anything that can be valued with money. ${ }^{3}$ The proceeds of crime are called dirty money or illegal money. Whereas, changing the proceeds of crime into legal is known as clean money or legal money. This is known as money laundering.

About how much money is laundered in money laundering activities cannot be known definitely. ${ }^{4}$ Some estimation have been made with very surprising results because the amount is equal to the third largest industry in the world, or 2 to $5 \%$ of Gross Domestic Product of the world, or approximately as much as US\$ 1 trillion where every year about US\$ 300 billion to US\$ 500 billion (or $30 \%$ to $50 \%$ ) of the amount of money "laundered" comes from drug trafficking. 5

Indonesia, as a country that participating in signed the 1988 Vienna Convention and ratified it on February 23, 1999. Then made Act No. 7 of 1997 concerning ratification of the United Nations Convention against Illicit Traffic in Narcotic Drugs and Psychotropic Substance, 1988. The 1988 Vienna Convention requires every country that has ratified to criminalize money laundering through statutory regulations. Some important provisions in the convention are article 3 (1) (a) which requires each member State to criminalize money laundering related to illicit trafficking of drugs, in addition to regulating the provisions of the list of violations relating to industry, distribution or illicit trafficking of drugs and its organization and management, or finances

\footnotetext{
${ }^{1}$ Mohammad Irvan Olii, 2005, "Sempitnya Dunia, Luasnya Kejahatan? Sebuah Telaah Ringkas Tentang Transnational Crime", Jurnal Kriminologi Indonesia Vol. 4 No. 1:14- 27: See also: Department of Economic and Social Affairs, 1976. A/CONF.56/ 10, Fifth United Nations Congress on the Prevention of Crime and the Treatment of the Offenders, Geneva, 1-12 September 1975, New York : United Nation. ${ }^{2}$ United Nations, Economic and Social Council (UNESCO), Problem and Dangers Posed by Organized Transnational Crime in the Various Regions of the World, World Ministerial Conference on Organized Transnational Crime, Naples, 21-23 November 1994, pp. 17-22.

${ }^{3}$ Irwansyah, W Hakim, and A Yunus, 2017. "Environmental audit as instrument for environmental protection and management", The Business \& Management Review 9 (2), 228-232.

${ }^{4}$ Benedictus Renny See, Ahmadi Miru, Muhadar, and Hasbir Paserangi. 2019. Know Your Customer (KYC) Principles Relates to Bank Confidentiality as an Effort to Prevent Money Laundering Crimes, Journal of Law, Policy and Globalization, Vol. 81, 12.

${ }^{5}$ See Sutan Remy Sjahdeini, 2003, "Kerugian Negara Akibat Pencucian Uang”, A Paper Presented on a discussion "Praktek Pencucian Uang dan Kerugian Negara” held by Pusat Pelaporan dan Analisis Transaksi Keuangan (PPATK) in cooperation with Indonesia Australia TAMF dan InterMatrix Communications, on Wednesday dated 16 April 2003 in Jakarta Media Center (JMC), Gedung Dewan Pers, Jakarta.
} 
from drug trafficking activities. ${ }^{1}$

In order to optimize performance, then the government updated the regulation on the eradication of money laundering ${ }^{2}$ with the enactment of Act No. 8 of 2010 concerning Prevention and Eradication of Money Laundering (UUPPTPPU) which in its explanation section states that one of the important content matters is concerning the granting of authority to the predicate criminal investigator to investigate the presumption of money laundering. As the provisions of article 2 paragraph (1) of the UUPPTPU, it is known that narcotics and psychotropic crime constitute 2 (two) of 26 (twenty six) types of predicate crime from money laundering.

However, if seen from a comparison between narcotics crimes and money laundering, there are significant differences. Based on press release data of BNN 2015 is known that from 90 narcotics criminal cases, only 12 cases represents money laundering crime. By assuming that each narcotics crime case has a different dealer, it means that from 90 drug dealers, there are only 12 drug dealers $(13.33 \%)$ whose money laundering is investigated.

Based on the aforementioned thoughts, to compare narcotics crimes with money laundering can be done by seeing how far narcotics or psychotropic crimes that are being handled can be developed for its money laundering. Ideally, all narcotics or psychotropic crimes can be developed into money laundering. Because where there is a narcotic or psychotropic crime, there is a suspect, and fund to the supplier, manufacturer, dealer or whatever the term and whoever is involved and enjoys the proceeds of the narcotics or psychotropic crime and makes it a source of livelihood.

Although the orientation of the eradication of money laundering crime and illicit drug trafficking is done using the follow the money approach, the follow the suspect approach cannot be ignored. The flow of money from proceeds of crime may be traced and confiscated to the state, even though it is actually rather difficult to imagine being able tracing and confiscation of assets without supported by the information of suspect. For that, the follow the money and the follow the suspect approaches need to be done simultaneously. Both cannot walk separately. Thus, the suspect must be arrested and detained. And to get maximum results in law enforcement, requires coordination and cooperation between law enforcers optimally.

\section{Method of Research}

The research is an empirical-legal research. The site of research was the National Narcotics Agency (BNN), the High Prosecutor of South Sulawesi, the High Court of Makassar, the Center of Financial Transaction Reports and Analysis (PPATK) and the Indonesian Supreme Court.

\section{Coordination of Authority among Law Enforcer in Handling Money Laundering in Narcotics Cases}

The National Narcotics Agency is a law enforcement institution that was established specifically to prevent and eradicate abuse and illicit trafficking of narcotics and precursors. It was situated in the center of Jakarta. In accordance with the Presidential Decree No. 23 of 2010 concerning the National Narcotics Agency, the Provincial National Narcotics Agency (BNNP - Badan Narkotika Nasional Provinsi) is a vertical agency of BNN that performs the duties, functions and authority of the National Narcotics Agency in the province.

The opening of access to authority for the National Narcotics Agency's investigators to trace assets of narcotics crime is essentially intended for the assets are confiscated for the State to be used for the purpose of preventing and eradicating the abuse of illicit trafficking of narcotics. Thus, access to the authority of the National Narcotics Agency's investigators to trace and find evidence of a narcotics suspect through the tracing of assets suspected of being the proceeds of a narcotics crime is possible through various means, sources and support as provided for in the Narcotics Act.

Based on the results of the research it is also known that in 2016, the national achievement of the eradication of the National Narcotics Agency in reveal drug syndicate reached 31 out of 22 targeted syndicates or $14.91 \%$, while the completion of investigation by TPPU was $86 \%$ (see Table 1 ).

\footnotetext{
${ }^{1}$ Yunus Husein, 2009. Kompilasi UU tentang Ratifikasi Konvensi PBB dan Standar Internasional Anti Pencucian Uang. (Revision ed) Jakarta : PPATK, p.2

${ }^{2}$ Yunus Husein, 2004, "Tindak Pidana Pencucian Uang (Money Laundering) dalam Perspektif Hukum Internasional”, Indonesian Journal of International Law, Vol. 1, No. 2.
} 
Table 1. Achievements of the National Narcotics Agency in the Field of Eradication in 2015-2016

\begin{tabular}{|c|c|c|c|c|c|}
\hline Year & Strategic Target & $\begin{array}{c}\text { Main Performance } \\
\text { Indicator }\end{array}$ & Target & Realization & Achievement \\
\hline \multirow{4}{*}{2015} & \multirow{4}{*}{$\begin{array}{l}\text { The increase of } \\
\text { disclosure of drug } \\
\text { syndicate networks and } \\
\text { the confiscation of drug } \\
\text { syndicate networks }\end{array}$} & $\begin{array}{l}\text { Number of arrested } \\
\text { syndicate networks }\end{array}$ & $\begin{array}{c}20 \\
\text { networks }\end{array}$ & 20 networks & $100 \%$ \\
\hline & & $\begin{array}{l}\text { Number of arrested and } \\
\text { completed } \\
\text { trafficking cases (P.21) }\end{array}$ & 278 case & 394 case & $141.7 \%$ \\
\hline & & $\begin{array}{l}\text { Number of money } \\
\text { laundering cases related to } \\
\text { the completed drug illicit } \\
\text { trafficking (P.21) }\end{array}$ & 14 case & 7 case & $50 \%$ \\
\hline & & $\begin{array}{l}\text { Asset value of confiscated } \\
\text { drug syndicate network }\end{array}$ & $\begin{array}{l}58,279 \\
\text { billion }\end{array}$ & $\begin{array}{l}85,109 \\
\text { billion }\end{array}$ & $146 \%$ \\
\hline \multirow[b]{2}{*}{2016} & \multirow{2}{*}{$\begin{array}{l}\text { The weakness activities } \\
\text { of narcotics illicit } \\
\text { trafficking syndicate } \\
\text { network }\end{array}$} & $\begin{array}{l}\text { Number of revealed } \\
\text { narcotics syndicate networks }\end{array}$ & $\begin{array}{c}22 \\
\text { networks }\end{array}$ & 31 networks & $140,91 \%$ \\
\hline & & $\begin{array}{l}\text { Percentage of money } \\
\text { laundering investigation } \\
\text { completion of narcotics } \\
\text { crime suspect proceeds from } \\
\text { a narcotics crime }\end{array}$ & $100 \%$ & $86 \%$ & $86 \%$ \\
\hline
\end{tabular}

Source: Primary data, 2019 (edited)

Based on the 2016 BNNs Government Agency Performance Accountability Report states that when compared to the achievements in 2015 there was an increase in the percentage of target achievement by $40.91 \%$, from $100 \%$ in 2015 to $140.91 \%$ in 2016 in terms of revealing narcotics syndicate networks. Furthermore, compared to the target at the end of strategic plan period 2019, the achievements in 2015 were 20 networks and in 2016 there were 31 networks (total 51 networks) have shown a significant increase $(41.8 \%)$ and it is expected that at the end of the period will remain maintained even improved.

Meanwhile, for the money laundering crime related to the completed narcotics illicit trafficking case (P.21) is a case of money laundering related to predicate crime (narcotics) which is revealed and investigated, after being declared complete then submitted to the attorney. If further studied from the revealing of 22 drug syndicate networks, only 4 syndicate networks with 5 suspects are indicated as being involved in money laundering cases. Even, most of it is the development of pre-existing cases. This shows the difficulty of revealing the money laundering in narcotics case, even in the case of narcotics syndicate network.

From the crime place, the revealed 22 drug syndicate networks in 2016 is found that nothing happened or comes from the jurisdiction of South Sulawesi. Thus, it can be ascertained that in locus delicti throughout 2016 no found the revealing of drug syndicate networks in the legal territory of the Provincial National Narcotics Agency of South Sulawesi. Considering that the drug syndicate network is a network that lives from a drug crime, it can also be ensured that in 2016 the revealing of money laundering in drug cases at the Provincial National Narcotics Agency of South Sulawesi is zero.

\section{Progressive Law Enforcement of Money Laundering in Narcotics Case}

The embodiment of progressive law enforcement is a manifestation of law enforcement of money laundering in narcotics case which places certainty, fairness and usefulness in parallel. Certainty is a manifestation of progressive law enforcement in an effort to implement formal legal procedures in obedient to everyone without exception. In the research context, the manifestation of progressive law enforcement against the money laundering crime in narcotics case in South Sulawesi is influenced by the variable of manifestation of authority coordination with indicators of institutional authority as well as support variables with indicators of physical and non-physical facilities.

In the variable of manifestation of authority coordination, a research showed that in essence the law enforcers related to the law enforcement of money laundering crime in narcotics case have known, understood and implemented all normative provisions outlined in the provisions of the law concerning the authority of the investigation by the Provincial National Narcotics Agency investigators of South Sulawesi; the authority to prosecute by the Public Prosecutor at the High Prosecutor of South Sulawesi; examination at a court hearing by the Panel of Judges at the High Court of Makassar for appeals and the Supreme Court for the cassation; appeal and cassation by the prosecutor, the suspect/defendant or his/her lawyer; and the execution of the Court's decision and the determination of the judge by the prosecutor as the executor.

The indicator of authority coordination is also related to normative provisions governing the pattern of relationships between laws enforcers related to the law enforcement of money laundering in narcotics case. 
However, in reality in the practice of law enforcement in money laundering crime in narcotics case, a number of problems, constraints and limitations were found, particularly regarding the support of physical and non-physical facilities which hampered the implementation of legal certainty ideally. The assertion that progressive law emphasizes adherence to formal legal procedures for everyone without exception including law enforcers, rather than ignoring it makes law enforcement against the money laundering crime in narcotics cases still seems to be accepted as it is now.

If adherence to formal procedural law has been fully performed, then the manifestation of law enforcement of money laundering crime in narcotics cases must fight for fairness in law enforcement. The concerned fairness is defined as a form of progressive law enforcement in an effort to fight the implementation of law materialsubstantive by listening to the conscience. ${ }^{1}$ The legal substance of the law enforcement of money laundering crime in narcotics case is to find proceeds from narcotics crimes that are owned, enjoyed, stored, disguised, and invested in other forms so that they appear to be assets obtained from legitimate business activities.

Although law enforcement officers in their duties face a number of problems, constraints and limitations, but in order to ensure a sense of legal justice in the law enforcement of money laundering crime in narcotics case, the investigators have moral obligation to trace the assets of the suspect/defendant to ensure whether or not the proceeds of crime are enjoyed by the suspect/defendant or other people, to indict and plead with the panel of judges for assets to be confiscated. These principles must be fought so that narcotics crime does not flourish and develop because confiscating the proceeds of crime can impoverish the suspect so that they cannot use the proceeds of their crimes again because they have been confiscated by the State.

After nine years the money laundering crime laws was established in 2010, how many these cases in narcotics cases have been prosecuted and decided? How many of 80 confiscated assets belonging to 110 drug leaders from 2010-2016 as the report of the National Narcotics Agency 2016 has investigated and submitted to the court in the money laundering crime?

Maybe there is or no because it seems that no court decision in inkracht of money laundering crime case from a suspect in a narcotics crime. Even 14 people sentenced to death in the narcotics case in 2015 - 2016 did not hear the development of the money laundering crime being submitted to the court. Not only to create discourse, but the researcher tried to find out the data of money laundering case (inkracht) in narcotics case at the Supreme Court level during the period of 2015-2017 through a search on the website of the High Court of Makassar, there were 26 tabs of Case Tracking System (SIPP - Sistem Informasi Penelusuran Perkara) for District Courts in South and West Sulawesi and to access do not require a special login.

As result of tracking we collect the decision for all types of criminal offenses and decided, namely cases from the High Court of Makassar, which have been decided (inkracht) at the Supreme Court level in the period 2015-2017, it found that:

1) During the period of 2015-2017 of the Supreme Court level, there were no special criminal decisions that had been decided (inkracht) for money laundering crime cases from the High Court of Makassar;

2) During the period of 2015-2017 of the Supreme Court level, there were 53 (fifty-three) special criminal decision on narcotics (and psychotropic) which have been decided (inkracht) from the High Court of Makassar for:

a) 1 (one) narcotics and psychotropic case in 2015 ;

b) 28 (twenty eight) narcotics cases in 2016 ;

c) 3 (three) narcotics and psychotropic cases in 2016 ;

d) 21 (twenty) narcotics and psychotropic cases in 2017 .

In addition, in June 2017 there was a special criminal decision without a statement of the type of criminal act, after checking it the contents of decision is a narcotic special criminal decision (inkracht). Thus, total inkracht at the site of research were 54 decisions.

For all the research findings and by looking at the cases that handled, it can be presented that the manifestation of the law enforcement of money laundering crime in narcotic case that puts justice on one line with legal certainty in essence wants to convey the message that obedience of law enforcers in formal procedural as a guarantee for legal certainty does not release the essence of the establishment of the money laundering crime laws, which impoverishes the suspect of crime through tracking and confiscation of assets as proceeds of criminal acts so as not to commit crimes again in the future.

In terms of justice, the impoverishment of the suspect is expected to treat sadness, disappointment, injury, material and immaterial loss, hope and aspiration of victims and their families who must struggle to survive, and then are expected to rise again from all the adverse effects of crime befall them due to the evil deeds of the suspect. In addition, to avoid new victims due to the crimes they have committed.

Sharpening conscience and fighting for a sense of justice by tracking and confiscating assets as proceeds of

\footnotetext{
${ }^{1}$ Burhanuddin, Abrar Saleng, Juajir Sumardi, and Abd. Maasba Magassing, The State's Responsibility in Fulfilling Domestic Energy Needs, Journal of Law, Policy and Globalization, Vol. 81, 34.
} 
narcotics crime is therefore an inevitable moral obligation. Moreover, the provisions of the law require that the investigation of the money laundering crime does not require proof that a narcotics crime has been committed.

The void of efforts to trace assets as indicated in 54 inkracht decisions of the narcotics case at the Supreme Court level during the period of 2015-2017 should stimulate the morality of law enforcement officials to jointly unite their perceptions and equalize steps to fight for the spirit of tracing and confiscating assets as proceeds of narcotics crime for the realization of money laundering law enforcement in a more just manner.

\section{Concussion}

The embodiment of money laundering law enforcement in narcotics case is a manifestation of progressive law enforcement which places certainty, fairness and usefulness in parallel. The law enforcement of money laundering in narcotics case will provide a guarantee of certainty if all law enforcers adhere to formal legal procedures without exception. The law enforcement of money laundering in narcotics case will give more fairness if it is able to convict suspect/perpetrator in accordance with the degree of guilt, be able to seize the proceeds of crime, be able to prevent the new victims, break the networks that support it.

The law enforcement of money laundering in narcotics case will provide maximum benefit if there is a strong synergy between the political will of the government, ${ }^{1}$ re-organization in the domain of law enforcement agencies, and its implementation nationally, so that the goal of order and happiness in society will be realized. Thus, it is important to always establish communication, cooperation and coordination between law enforcement agencies in order to unite perceptions and equalize steps for optimal efforts to the law enforcement of money laundering crime in narcotic case.

\section{References}

Aminuddin Ilmar. 2004. Hukum Penanaman Modal di Indonesia. Kencana: Jakarta.

Barda Nawawi Arief, 2000. Kebijakan Legislatif dalam Penanggulangan Kejahatan dengan Pidana Penjara, Semarang : Badan Penerbit Undip.

Benedictus Renny See, Ahmadi Miru, Muhadar, and Hasbir Paserangi. 2019. Know Your Customer (KYC) Principles Relates to Bank Confidentiality as an Effort to Prevent Money Laundering Crimes, Journal of Law, Policy and Globalization, Vol. 81, 12.

Burhanuddin, Abrar Saleng, Juajir Sumardi, and Abd. Maasba Magassing, The State's Responsibility in Fulfilling Domestic Energy Needs, Journal of Law, Policy and Globalization, Vol. 81, 34.

Department of Economic and Social Affairs, 1976. A/CONF.56/ 10, Fifth United Nations Congress on the Prevention of Crime and the Treatment of the Offenders, Geneva, 1-12 September 1975, New York: United Nation.

Irwansyah, W Hakim, and A Yunus, 2017. "Environmental audit as instrument for environmental protection and management", The Business \& Management Review 9 (2), 228-232.

Mohammad Irvan Olii, 2005, "Sempitnya Dunia, Luasnya Kejahatan? Sebuah Telaah Ringkas Tentang Transnational Crime”, Jurnal Kriminologi Indonesia Vol. 4 No. 1:14- 27.

Romli Atmasasmita, 2011, Sistem Peradilan Pidana Kontemporer, Jakarta: Kencana.

Sutan Remy Sjahdeini, 2003, “Kerugian Negara Akibat Pencucian Uang”, A Paper Presented on a discussion "Praktek Pencucian Uang dan Kerugian Negara" held by Pusat Pelaporan dan Analisis Transaksi Keuangan (PPATK) in cooperation with Indonesia Australia TAMF dan InterMatrix Communications, on Wednesday dated 16 April 2003 in Jakarta Media Center (JMC), Gedung Dewan Pers, Jakarta.

United Nations, Economic and Social Council (UNESCO), Problem and Dangers Posed by Organized Transnational Crime in the Various Regions of the World, World Ministerial Conference on Organized Transnational Crime, Naples, 21-23 November 1994, pp. 17-22.

Yunus Husein, 2004, "Tindak Pidana Pencucian Uang (Money Laundering) dalam Perspektif Hukum Internasional", Indonesian Journal of International Law, Vol. 1, No. 2.

Yunus Husein, 2009. Kompilasi UU tentang Ratifikasi Konvensi PBB dan Standar Internasional Anti Pencucian Uang. (Revision ed) Jakarta : PPATK.

\footnotetext{
${ }^{1}$ Aminuddin Ilmar. 2004. Hukum Penanaman Modal di Indonesia. Kencana: Jakarta.
} 